\title{
Does Climatic Seasonality of the Caatinga Influence the Composition of the Free lists of Medicinal Plants? A Case Study
}

\author{
Ernani Machado de Freitas Lins Neto ${ }^{1,2^{*}}$, Silvana Vieira dos Santos ${ }^{3}$, and Washington Soares Ferreira Júnior ${ }^{4}$ \\ ${ }^{1}$ Programa de Pós-Graduação em Ciências da Saúde e Biológicas, Universidade Federal do Vale do São Francisco (UNIVASF), \\ Campus Petrolina, Pernambuco, Brazil. ²Programa de Pós-Graduação em Ecologia Humana e Gestão Socioambiental \\ (PPGEcoH), Departamento de Tecnologia e Ciências Sociais (DTCS) Campus III da Universidade do Estado da Bahia, Bahia, \\ Brazil. ${ }^{3}$ Colegiado de Ciências da Natureza, Universidade Federal do Vale do São Francisco, Campus de Senhor do Bonfim, \\ Bahia, Brazil. 'Laboratório de Investigações Bioculturais no Semiárido, Universidade de Pernambuco (UPE), Campus \\ Petrolina, Brazil. \\ *ernani.linsneto@univasf.edu.br
}

\begin{abstract}
The free list is a key data collection tool in ethnobotanical studies. For this reason, it is currently receiving a great deal of attention regarding possible methodological limitations. To this end, we aim to investigate the influence of climatic seasonality of the Caatinga ecosystem on the composition of free lists of medicinal plants provided by people from a rural community located in the northeast region of Brazil. People were asked the same trigger question (which medicinal plants do you know?), during the rainy and dry seasons. Comparing the plant lists described during both periods (68 plants), respondent salience in the rainy period was significantly higher than the dry period. However, similarities can be observed between the two lists, especially with respect to their composition and the continued importance of hortelã (Mentha sp.) and alecrim (Lippia sp.), which maintained prominent positions during the rainy and dry seasons. The general analysis of the free lists revealed that there were no significant differences due to temporality, especially in relation to plants with a higher salience value. Since these plants are found mainly in homegardens, it is possible to deduce that the daily conduct of activities in these environments is stimulating and keeping plants in homegardens active in people's memory. However, much still needs to be investigated about the free list technique in ethnobotanical data collection, especially with regard to the influence of seasonality on stimulating seasonal diseases.
\end{abstract}

Received February 11, 2020

OPEN ठACCESS

Accepted December 24, 2020

DOI 10.14237/ebl.12.1.2021.1678

Published March 15, 2021

Keywords Salience index, Relative importance index, Dry forest, Ethnobotany

Copyright (c) 2021 by the author(s); licensee Society of Ethnobiology. This is an open-access article distributed under the terms of the Creative Commons Attribution-NonCommercial 4.0 International Public License (https://creativecommons.org/licenses/by-nc/4.0), which permits non-commercial use, distribution, and reproduction in any medium, provided the original author and source are credited.

Supplementary Files available at https://doi.org/10.14237/ebl.12.1.2021.1678

\section{Introduction}

The free list is a key data collection tool in ethnobiological studies (Cardoso et al. 2017; Miara et al. 2019; Quinlan 2005), representing a quick and very efficient way to access the repertoire of items (e.g., resources) in a given domain of knowledge in a human group (Quinlan 2005). For example, a research participant could be invited to list all the medicinal plants that people in a given community use. By compiling all lists of medicinal plants produced by community residents, it is possible to delimit the local domain of medicinal plant knowledge (see Quinlan 2005).

Some assumptions have been made by different authors when applying the free list technique (see Smith 1993; Quinlan 2005). For example, in free lists, it is important to consider how often a given item appears and the order in which it is cited in different lists. This is because the most important items for a group tend to be the most frequently cited and listed first (Smith 1993; Quinlan 2005). This set of items ordered through memory retrieval provides a starting 
point for the development of many ethnobiological studies. For this reason, the scientific community has increasingly focused on this data collection technique, seeking to understand its operation and limitations in order to improve this tool progressively (e.g., Sousa et al. 2016).

Although it is one of the main techniques for collecting ethnobiological information, few investigations test the free list in different socioecological contexts to assess whether the lists can respond, for example, to seasonal variations in climate. When considering seasonal environments, resource availability and human strategies linked to the environment may be distinct at different seasons in the same year (Campbell et al. 1997; Shankar et al. 1998). Ramos and Albuquerque (2012) showed that the composition of firewood used might differ in a rural community in different seasons (rainy and dry), while diseases may vary in incidence due to changes in temperature and humidity at different times of the year (Ong et al. 2018; Wu et al. 2016). Changes in disease incidence throughout the year may also affect the use of medicinal plants in different seasons and, in this case, affect the order and frequency of citation of medicinal resources in free lists. For example, the study by Sousa et al. (2016) observed that the order of remembered items and the composition of free lists of medicinal plants is associated with the recent use of resources.

Thus, we investigate the following question: in environments with marked and seasonal climatic variations, is the composition of free lists affected by seasonality? We expect to find differences in plant positions when comparing the rainy season with the dry season in the Caatinga, a seasonally dry tropical forest. A second question then arises: do the most
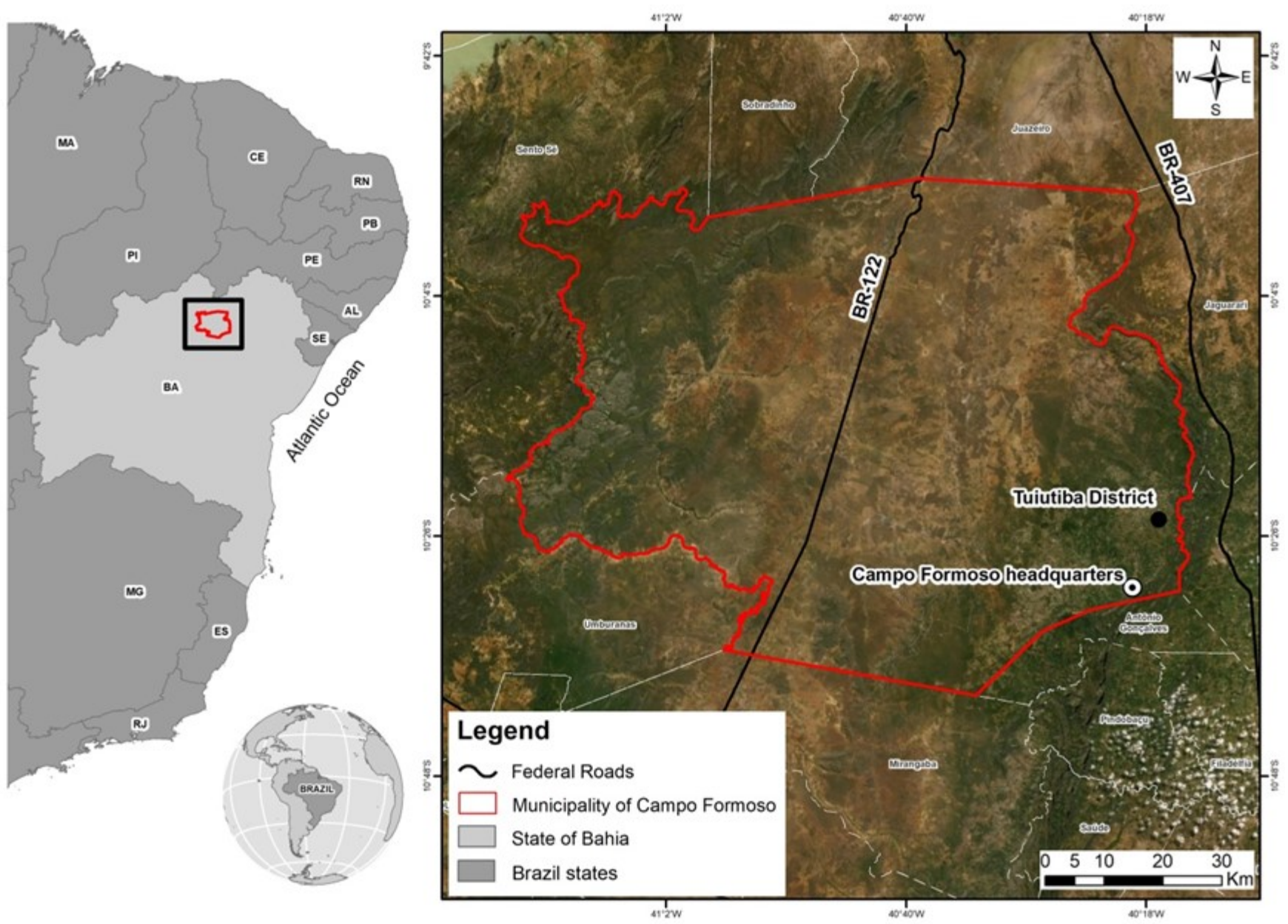

Figure 1 Map of the municipality of Campo Formoso-BA with emphasis on the district of Tuiutiba, where the study was conducted. 
versatile plants show less variation in their positions over time? Given that recent usage may be important in the composition of the list, it is expected that these very versatile plants will also be widely used at different times of the year.

\section{Methods}

Study Area

The study was conducted in the rural community of Tuiutiba, belonging to the municipality of Campo Formoso (Figure 1). Tuiutiba district, which is about 15 kilometers away from Campo Formoso, is typically rural, having its main agricultural activities based on maize, beans, and cassava, as well as commercial activities, although the locality also has a strong potential for emerald mining. The climate is dry subhumid with rainfall reaching up to $900 \mathrm{~mm}$. It has a dense tree vegetation with fragments of seasonal forests.

All residents who agreed to participate in the study were invited to sign the Informed Consent Form (ICF). This study was approved by the UNIVASF Research Ethics Committee (CAEE N ${ }^{\circ}$ : 87412418.2.0000.5196).

\section{Data Collection}

The study was conducted at the district headquarters of the Tuiutiba, where there are approximately 300 households. Almost all residencies were visited, however only 22 residents agreed to participate in the study. These residents are adults responsible for their residence or willing to participate in the research. It is noteworthy that there was a great hesitation of people to participate in the research, mainly due to the need to return for a new interview. However, as houses were being visited, we asked residents "which people in the community are very knowledgeable about medicinal plants?" By asking this question, we found that the majority of the 22 informants who agreed to participate in the study, 14 of the people who fall between the ages of 40 to 90 years old, are recognized locally as "experts" on medicinal plants. In this way, we were able to minimize the problem of low sampling since the list of plants generated at both times was produced from people with a closer relationship with the plants. Like this, we collected socioeconomic data related to age, gender, residence time in the locality, and monthly income from participants. Ethnobotanical data collection was divided into two stages. In the first stage, the free list technique was applied during the rainy season from
June to September 2018. At the time, participants were asked to list the medicinal plants they use and/or know from the triggering question: Which medicinal plants do you know? Each plant was recorded strictly in the order in which it was cited by the participant.

In possession of the list provided by each informant, a semi-structured questionnaire was applied with questions directed to the use of each mentioned plant, such as: Which disease is this plant indicated for?, Where do you collect it?, and Which part do you use? This same procedure was repeated for the dry season, which was carried out from January to March 2019. In the dry season, the same people from the previous stage were invited to participate. For the second stage, only 19 people participated, three people fewer than the survey undertaken during the rainy season.

\section{Data Analysis}

Based on the free lists, the salience of the plants cited as medicine was analyzed from the salience index (SI), which considered the frequency of citation and the average position of the items in the lists obtained (Smith and Borgatti 1997) based on the following formula:

$$
\mathrm{SI}=\left(\sum\left(\left(\mathrm{Li}-\mathrm{R}_{\mathrm{j}}+1\right) / \mathrm{Li}\right)\right) / \mathrm{N}
$$

where $\mathrm{SI}=$ salience index, $\mathrm{Li}=$ size of the list where the term is cited, $R_{j}=$ position of the item in a given list $\mathrm{Li}$, and $\mathrm{N}=$ total number of lists (or interviewed).

This way, the most salient items involve a high citation in several lists and are primarily remembered. The SI was calculated for plants from both dry (considering the 19 lists obtained in this period) and rainy (considering the 22 lists obtained) season lists. Each plant could then have two distinct salience values. In addition, we employed the protocol proposed by Chaves et al. (2019) to identify the most salient plants by comparing the observed salience with a null model derived from randomization in the free lists of medicinal plants. This analysis involves a new proposal to identify statistically salient plants from free lists. The null scenario was produced from the generation of 1000 simulated populations, each containing the same number of participants and plants from the studied community, but with a randomization of the frequency and order of plant citation in the free lists. In this way, the plant salience values obtained from each simulated population were used to construct a null distribution. In this sense, the observed values of salience of each plant (in each 
season) were compared with the values obtained in the null distribution. Details of the stages in this analysis can be found in Chaves et al. (2019). Thus, the observed salience values that stand out significantly from those expected by the null model involve the most salient plants in the studied community (see Chaves et al. 2019). Then, the plants were divided into three groups: the first formed by plants that had significantly high salience values in relation to the null scenario; a second group includes the observed values that do not differ from the null scenario; and the third group of plants comprises plants whose salience values are significantly low compared to the null model. This group probably includes the least prominent medicinal plants for the participants. All stages of this analysis were carried out for both the dry season and the rainy season separately and were performed using R, version 3.4.3, (R Development Core Team 2018) and the script developed is available as supplementary material online (Supplementary Material - R Markdown). It should be noted that it is necessary that the script Salience_V2.R, be present in the directory folder, otherwise the analysis will not run. The script Salience_V2.R is available as supplementary material in Chaves et al. (2019) (function labeled as salience). This analysis was important for the selection of the most important plants in the two periods analyzed, allowing a quick and easy reproducibility comparison.

The paired t-test was applied to compare the two final lists produced in the two evaluation periods. The present analysis focused only on the set of species that stood out in the dry or rainy period in relation to the salience values to assess whether the species with the highest salience in the community can be different depending on the period of the year in which the free lists are applied. In this case, when demonstrating that the salience of these species can be changed at different times of the year in the same community, this may suggest that we need to be concerned with the time of data collection through free lists in markedly seasonal environments. From this test, we evaluated whether the species that remain prominent over time show greater therapeutic salience compared to species that do not remain prominent in different evaluation periods. To compare the lists in the two periods, dry and rainy, a paired t-test at 5\% probability was used. This analysis was performed using the program $\mathrm{R}$ version 3.4.3 ( $\mathrm{R}$ Development Core Team 2018) and the script developed is available as supplementary material online (Supplementary Material - R Markdown).

To answer our second research question, the relative importance index (Bennett and Prance 2000) was applied to evaluate the versatility of each ethnospecies mentioned. For this calculation, it is assumed that the importance of a plant is linked to the number of therapeutic indications and body systems it meets. The index ranges from 0 to 2 , where ethnospecies with values closer to 2 are considered more important. The calculation is based on the following formula:

$$
\mathrm{RI}=\mathrm{NBS}+\mathrm{NP}
$$

where RI = relative Importance of a given species; NBS = number of body systems; being calculated by the number of body systems that a given species is indicated divided by the number of body systems that the most versatile species is indicated for treatment; and NP = number of therapeutic indications; being calculated by the number of therapeutic indications of a given species divided by the number of therapeutic indications that the most versatile species is indicated for treatment.

Despite the construction of the free list in two stages, only the information collected in the rainy season was considered to calculate the relative importance of the plants, due to the higher number of plants cited in this period. To perform the RI calculation, a simple function was built in the $\mathrm{R}$ environment called RI_MP.R, described in the supplementary material.

\section{Results}

From the interviews, 140 and 85 ethnospecies were recorded for the rainy and dry seasons, respectively. Of these, 73 were cited exclusively in the rainy season, 18 were cited exclusively in the dry season, and 67 were cited in both periods. From the second list (dry season), seven species showed significantly higher salience values than the random scenario $(p<0.05)$. In this case, we selected the seven most salient species from the two lists produced (rainy and dry seasons) that stood out in relation to the null model (Figure 2). In order of decreasing salience index (SI), the following stand out in the list of the rainy season (Table 1): hortelã (Mentha sp.) (IS = 0.565) followed by malvão (Pavonia sp.) (IS = 0.456), arruda (Ruta graveolens) $(\mathrm{IS}=0.428)$, capim-santo (Cymbopogon citratus) (IS = 0.418), alecrim (Lippia sp.) (IS = 0.386), ervacidreira (Melissa officinalis) (IS $=0.371$ ), and sweet 


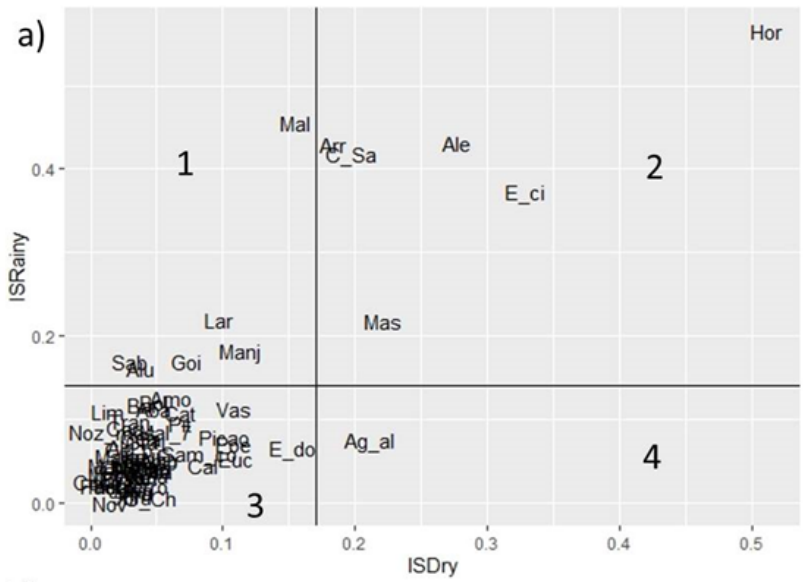

b)

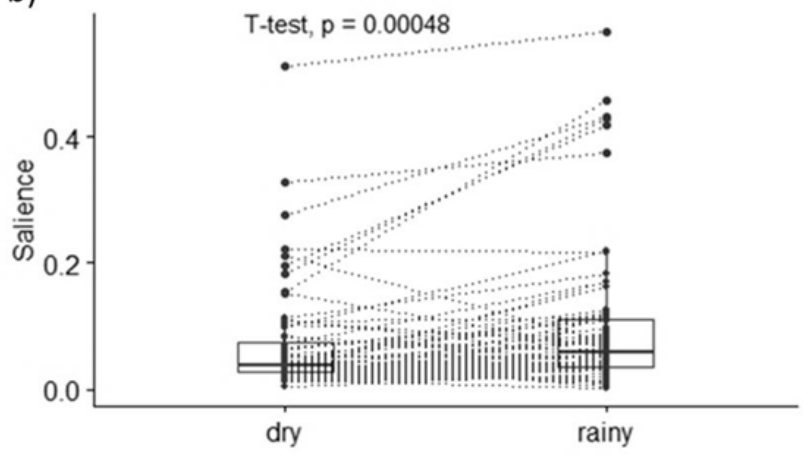

Figure 2 Salience of medicinal plants in the rainy and dry period. A Scatterplot showing medicinal plants with higher values of salience, which differ from the null model, in the rainy (quadrants 1 and 2) and dry (quadrants 2 and 4) seasons. Quadrant 3 has the other plants (with salience values that do not differ from the null model and the lowest values, which differ from the null model). Acronyms of plants in quadrants 1,2 , and 4 : Hor $=$ Hortelã; Ale = Alecrim; Arr = Arruda; C_Sa = Capim Santo; E_ci $=$ Erva Cidreira; Mas = Mastruz; Mal = Malvão; Lar = Laranja; Manj = Manjericão; Goi = Goiaba; Alu = Alumã; $\mathrm{Sab}=$ Sabugueira; and $\mathbf{A g} \_\mathrm{al}=$ Água de alevante. $\mathbf{B}$ Whisker plots of the paired t-test of the salience of the 68 medicinal plants mentioned in both the dry and rainy seasons.

orange (Citrus sp.) (IS $=0.222)$. In the list produced during the dry season (Table 1), hortela (Mentha sp.) remained in the first position (IS $=0.563$ ) followed by erva-cidreira (Melissa officinalis) (IS $=0.364$ ), alecrim (Lippia sp.) (IS = 0.306), mastruz (Chenopodium ambrosioides) (IS $=0.243)$, água-de-alevante (Malva sp.) $($ IS $=0.211)$, arruda (Ruta graveolens) $($ IS $=0.203)$ and capim-santo (Cymbopogon citratus) (IS $=0.197$ ). Comparing the lists in these two periods (Table 1), considering only the plants that appeared in both lists
(68 plants), the salience in the rainy period was significantly higher than the dry period $(\mathrm{t}=3.6735$, df $=67, \mathrm{p}$-value $=0.0004768)($ Figure 2$)$.

However, similarities can be observed between the two lists, especially with respect to their composition, specifically bortelã and alecrim, which maintained their prominent positions during the rainy and dry seasons. Among the plants that showed significantly high salience values in relation to the null model in the dry period (7 plants), six also showed prominence in the salience values during the rainy season. The rainy season presented a higher number of species that stood out in relation to the high salience values (12 plants) when compared to the dry season. However, even with the observed reduction in the number of species with significantly high salience values in the dry season, it concentrated on species also with high salience in the rainy season. Only águade-alevante (Malva sp.), which was prominent in the dry season, did not show a significantly higher salience value than the null model during the rainy season. In the rainy season, six plants presented significantly higher salience values than the random scenario, which do not appear to be prominent in the dry season, such as malva (Pavonia sp.), sweet orange (Citrus sp.), manjericão (Ocimum basilicum), sabugueiro (Sambucus australis), goiaba (Psidium guajava), and alumã (Vernonia sp.).

When assessing the relative importance of ethnospecies, it was found that the ten most important, in descending order of relative importance index $(\mathrm{RI})$, are: hortela $(\mathrm{RI}=2.000)$, manjericão $(\mathrm{RI}=$ 1.727), alecrim $(\mathrm{RI}=1.651)$, capim-santo $(\mathrm{RI}=1.561)$, limão $(\mathrm{RI}=1.561)$, malvão $(\mathrm{RI}=1.561)$, goiaba $(\mathrm{RI}=$ 1.379), laranja $(\mathrm{RI}=1.303)$, arruda $(\mathrm{RI}=1.227)$, and erva-doce $(\mathrm{RI}=1.197)$. Of these, six are among the most prominent ethnospecies, highlighting again bortela and alecrim, which remained in the first and third position, respectively. Regarding the uses attributed to the prominent species only in the rainy season, we observed that they are mainly indicated for the treatment of diseases of the gastrointestinal system (diarrhea, liver, and intestine problems) and the respiratory system (influenza) with leaves being the main part used. An exception is the sabugueiro, which has its flowers used instead. These plants are primarily found in the backyards of the houses, according to participants.

The six most prominent ethnospecies that remain in the two evaluated periods are mainly used to treat 
respiratory system diseases (influenza, cough, sore throat, and bronchitis, particularly bortelã and alecrim), gastrointestinal disorders (belly ache, particularly arruda), for the treatment of wounds and inflammation (mastrus) and as soothing (mainly capim santo and erva cidreira). The most used part of these ethnospecies are the leaves, consumed mainly in the form of teas, infusions, or syrups. All informants reported the collection of the six plants in residential areas, with $86 \%$ collecting in their own backyards and the remaining 14\% collecting exclusively in neighbors and/or parents' backyards. Informants indicated that they use, whenever necessary, the previously mentioned medicinal species. These results, finally, suggest that the two groups of plants, which remained detached in the two periods and those that stood out only in the rainy season, do not differ in their uses, parts used, or in relation to the place of collection.

Comparing the final lists of the two periods in relation to plants that had significantly low salience

Table 1 List of medicinal plants with significative salience values (SI) (rainy and dry seasons) and relative importance (RI) obtained from information shared by people from the Tuiutiba community, Campo Formoso, Bahia.

\begin{tabular}{|c|c|c|c|c|c|c|c|}
\hline $\begin{array}{l}\text { Ethnospecies } \\
\text { (Species name) }\end{array}$ & Uses & Part used & SI rainy & $P$ value & IS dry & $P$ value & $\mathbf{R} \mathbf{I}$ \\
\hline $\begin{array}{l}\text { Água De Alevante } \\
\text { (Malva spicata) }\end{array}$ & Flu, heart and blood pressure & $\begin{array}{l}\text { Leaf, } \\
\text { flower }\end{array}$ & 0.076 & 0.369 & 0.211 & 0.006 & 0.606 \\
\hline $\begin{array}{l}\text { Alecrim } \\
\text { (Rosmarinus } \\
\text { officinalis) }\end{array}$ & $\begin{array}{l}\text { Syrup, hair loss, fever, body aches, cough, } \\
\text { Flu, sore throat, soothing and diabetes }\end{array}$ & Leaf & 0.385 & 0.000 & 0.306 & 0.000 & 1.651 \\
\hline $\begin{array}{l}\text { Alumã } \\
\text { (Vernomia sp.) }\end{array}$ & $\begin{array}{l}\text { Heartburn, gas, weight loss, bowel, liver } \\
\text { and } \\
\text { stomach pain }\end{array}$ & Leaf & 0.162 & 0.023 & 0.035 & 0.217 & 0.879 \\
\hline $\begin{array}{l}\text { Arruda } \\
\text { (Ruta graveolens) }\end{array}$ & $\begin{array}{l}\text { Menstrual cramps, stomach ache, } \\
\text { intestinal cramps, praying, gas, stomach } \\
\text { ache, sitz bath and } \\
\text { Spiritual healing }\end{array}$ & Leaf & 0.428 & 0.000 & 0.203 & 0.009 & 1.228 \\
\hline $\begin{array}{l}\text { Babosa } \\
\text { (Aloe vera) }\end{array}$ & Cancer and Hair Loss & Leaf & 0.050 & 0.386 & 0.058 & 0.448 & 0.606 \\
\hline $\begin{array}{l}\text { Capim Santo } \\
\text { (Cymbopogon } \\
\text { citratus) }\end{array}$ & $\begin{array}{l}\text { Soothing, Kidneys, Insomnia, Urinary Tract } \\
\text { Infection, Blood Pressure, Belly Ache, } \\
\text { Immunity }\end{array}$ & Leaf & 0.418 & 0.000 & 0.197 & 0.012 & 1.561 \\
\hline $\begin{array}{l}\text { Erva Cidreira } \\
\text { (Melissa officinalis) }\end{array}$ & $\begin{array}{l}\text { Soothing, stomach ache, gases, poor } \\
\text { digestion and blood pressure }\end{array}$ & Leaf & 0.371 & 0.000 & 0.367 & 0.000 & 1.121 \\
\hline $\begin{array}{l}\text { Goiaba } \\
\text { (Psidium guajava) }\end{array}$ & $\begin{array}{l}\text { Diarrhea, slimming, nausea, blood } \\
\text { pressure, hair loss and teething }\end{array}$ & $\begin{array}{l}\text { Bark, } \\
\text { fruit, Leaf } \\
\text { Young, } \\
\text { Leaf }\end{array}$ & 0.169 & 0.016 & 0.079 & 0.384 & 1.379 \\
\hline $\begin{array}{l}\text { Hortelã } \\
\text { (Mentha sp.) }\end{array}$ & $\begin{array}{l}\text { Stroke, stomach ache, headache, } \\
\text { numbness, fever, flu, syrup, evil eye, } \\
\text { cough, menstrual cramps and } \\
\text { Sore throat }\end{array}$ & Leaf & 0.565 & 0.000 & 0.562 & 0.000 & 2.000 \\
\hline $\begin{array}{l}\text { Laranja } \\
\text { (Citrus sp.) }\end{array}$ & $\begin{array}{l}\text { Soothing, headache, fever, flu, } \\
\text { syrup and coughing }\end{array}$ & $\begin{array}{l}\text { Fruit, } \\
\text { Leaf }\end{array}$ & 0.222 & 0.002 & 0.055 & 0.419 & 1.303 \\
\hline $\begin{array}{l}\text { Malvão } \\
\text { (Pavonia sp.) }\end{array}$ & $\begin{array}{l}\text { Bronchitis, belly ache, flu, bloating, } \\
\text { syrup, coughing and infection }\end{array}$ & Leaf & 0.456 & 0.000 & 0.155 & 0.051 & 1.561 \\
\hline $\begin{array}{l}\text { Manjericão } \\
\text { (Ocimum basilicum) }\end{array}$ & $\begin{array}{l}\text { Syrup, bathing, earache, headache, hair } \\
\text { loss, diabetes, pressure and food }\end{array}$ & Leaf & 0.183 & 0.009 & 0.099 & 0.246 & 1.727 \\
\hline $\begin{array}{l}\text { Mastruz } \\
\text { (Chenopodium } \\
\text { ambrosioides) }\end{array}$ & $\begin{array}{l}\text { Injury, Infection, Inflammation, } \\
\text { Bruises, lung and worm }\end{array}$ & Leaf & 0.218 & 0.002 & 0.243 & 0.002 & 1.045 \\
\hline $\begin{array}{l}\text { Sabugueiro } \\
\text { (Sambucus australis) }\end{array}$ & $\begin{array}{l}\text { Syrup, chicken pox, flu and } \\
\text { Cough }\end{array}$ & $\begin{array}{l}\text { Flower, } \\
\text { Leaf }\end{array}$ & 0.170 & 0.016 & 0.033 & 0.187 & 0.864 \\
\hline
\end{tabular}


values $(p<0.05)$, we observed that 21 plants had low salience values in the rainy season and six in the dry period. Moreover, neither of these plants was repeated in both periods (Table 1). This indicates that the group of plants of lesser prominence are distinct in two close periods of free-list data collection, which is different from that observed for the species with high salience.

\section{Discussion}

The temporal variation, according to the results presented above, did not influence the composition of the free lists when considering some of the most salient and versatile medicinal plants, since six of the seven plants that stood out in the dry season also had high salience values in the rainy season. This result corroborates the findings by Ramos and Albuquerque (2012), who observed that the use of a small set of very important plants used locally as fuels did not vary between the dry and rainy period over a year of monitoring in a human group in northeastern Brazil. Although the research by Ramos and Albuquerque (2012) considered uses for different purposes, a comparison with our results suggests that climate seasonality does not affect the use of some important plants and, in parallel, the salience of these resources over a year. Our findings about the plants with lower salience values, which were very different in the two periods studied, supports this suggestion.

However, a number of plants with higher values of salience in the rainy season did not stand out in the free lists during the dry season. These plants share characteristics with the group that stood out in both periods, being highly versatile, indicated for diseases of the gastrointestinal and respiratory system, and mainly found in the backyards of houses. In relation to versatility, we observed that certain highly versatile plants may present an outstanding salience at a certain time of the year (rainy season), but not at another (dry) period. In this case, it would not necessarily be the versatility that would lead to these differences in the two periods. Although they share certain characteristics, other factors may be important in medicinal use, such as therapeutic efficiency and organoleptic properties. Other research suggests that perceived taste and smell are important in indicating plants for disease treatment (Brett and Heinrich 1998; Geck et al. 2017) and that plants perceived as more palatable may be more commonly used by people for certain diseases (Santos et al. 2018). In addition, the perception of therapeutic efficiency of a species may favor its use over other plants for different diseases (Santos et al. 2018). It is possible that, in addition to the shared characteristics, the interaction with other important properties in medicinal use (organoleptic and therapeutic efficiency) can explain why certain locally relevant plants did not stand out in the two periods studied. Perhaps these plants are not as palatable or efficient when compared to those that showed significantly high salience values in both periods.

In this sense, the six species that presented higher salience values in both periods probably have a combination of characteristics (that we were not able to define here) that result in a better return on medicinal use (see Albuquerque et al. 2019). These species resemble the "traditional first aid kit," as a small set of species maintained by people who are indicated for the treatment of the most common diseases (see Menendez-Baceta et al. 2015; Pardo-deSantayana et al. 2015). Furthermore, it is possible that these species make up the so-called "structural core" of the medical system studied. The structural core was defined by Ferreira Júnior and Albuquerque (2015) as a set of plants that have important characteristics in medicinal use that favor the structure and functionality of the local medical system. In this case, the six plants that stood out in the two periods have important characteristics with respect to their use, accessibility, versatility, and treatment for important groups of diseases, considering that gastrointestinal and respiratory diseases tend to be fairly cited by different human groups in the Brazilian semiarid region (see Albuquerque et al. 2007) and in other regions of the world (Bradacs et al. 2011; Giovannini 2015; Güler et al. 2020; Monigatti et al. 2013; Suárez 2019). In this case, other characteristics may be linked to these plants that justify their high salience values in the two periods, as mentioned in the previous paragraph, but which were not evaluated in the present study. In addition, Ferreira Júnior and Albuquerque (2015) hypothesize that the structural core represents a component of the system that varies little over time, due to its importance. This may further reinforce the idea that the six prominent plants make up the structural core. This may reflect human adaptive strategies in their interactions with resources in the environment, so that more important resources are favored in memory during the elaboration of the free lists, which leads to the idea of adaptive memory (see Nairne et al. 2007; Sandry et al. 2013). When evaluating the idea of adaptive memory in the context 
of medicinal plants, Silva et al. (2019) performed an experiment with university students to memorize cards with information on medicinal plants indicated for the treatment of diseases and, after a period of distraction, participants were asked to remember the information previously presented (Silva et al. 2019). The authors found that priority-remembered plants were previously known to participants, regardless of whether they were linked to dangerous diseases or not. This suggests that having previous experience with a resource may favor its memorization. In turn, these plants can be mentioned more in the first positions of the free lists, favoring their salience.

Thus, considering that respiratory tract diseases are quite cited in both periods studied, especially in the rainy season, maintaining a repertoire of plants to fight such diseases is an important adaptive strategy. In addition, these plants are quite affordable for people and are versatile, which may suggest that they are widely used. This use favors people's experiences with these plants, allowing them to be ranked in the top positions on different free lists. This idea also corroborates the explanation proposed by the Socioecological Theory of Maximization, which indicates that human groups build social-ecological systems through cognitive and behavioral mechanisms to favor their survival by decreasing costs and maximizing returns on their interactions in different environments (Albuquerque et al. 2019). The indication of more salient plants that have important characteristics for the treatment of diseases (versatility and accessibility) reflects a strategy for people to deal with diseases.

Similarly, ensuring the availability of these frequently accessed resources is also prudent. In this sense, plants with higher salience values are available in the residential yards of the Tuiutiba community. In the current social organization of the community, it is a woman's task to maintain the backyards, resulting in their daily contact with the plants located in this environment. Thus, it is concluded that such continuous stimulation is also responsible for the immediate memorization of the plants (Sousa et al. 2016) used in the treatment of respiratory tract and related disorders. In this sense, this most recently used memory associated with a particular disease, as well as the spatial context of the backyards, are crucial in the development of autonoetic memory associated with the use of medicinal plants (Kahana 1996;
Mickes et al. 2013; Sousa et al. 2016; Spiller and Unsworth 2011).

It should be noted that the findings of the present paper cannot be generalized to the entire study community or to other communities, due the limitations such as the small number of research participants. However, by applying the free list technique under two climatic conditions with the same set of people, it was possible to observe certain plants with differential salience values at both moments. This may be an indication that the importance of a plant (measured by the salience) for a given group of people interviewed may vary, depending on when the interviews are taking place. In this case, in addition to seasonality, other factors can influence the composition of free lists, such as the place where the interviews are conducted (see Miranda et al. 2007) or aspects related to the participants' memory (Brewer 2002). Thus, we think that much still needs to be investigated about the free list technique in ethnobotanical data collection (Sousa et al. 2016). However, seasonal climatic conditions provide a particular environment for the development of certain diseases for which a specific plant repertoire is employed. These, in turn, have their availability and access guaranteed in highly anthropogenic environments, like backyards, where they are managed for on-demand use. Further studies need to be conducted, especially in the longer term, to provide more detailed information on the dynamics of knowledge and use of medicinal plants in the composition of free lists.

Finally, it is important to indicate that we use the ethno-species unit since, based on Sousa et al. (2016), knowledge is individual, and the informant will not name the same species differently at different times. Anyway, to ensure that the informants were referring to the same plant, all plants that stood out in relation to the salience values were identified through comparisons with material in existing herbariums, consultations with experts, and references in specialized literature. However, it is possible that the same participant indicated two different names for the same plant in the two periods of application of the free lists, which would limit the findings particularly for plants that did not stand out in the salience values.

\section{Acknowledgments}

The authors would like to thank the community "Tuiutiba" for the reception and support during the 
field stages. This study was financed in part by the Coordenação de Aperfeiçoamento de Pessoal de Nível Superior - Brazil (CAPES) Finance Code 001.

\section{Declarations}

Permissions: The informants who agreed to participate in the study were invited to sign the Informed Consent Form (ICF). This study was approved by the UNIVASF Research Ethics Committee (CAEE N ${ }^{\circ}$ : 87412418.2.0000.5196).

Sources of funding: None declared.

Conflicts of Interest: None declared.

\section{References Cited}

Albuquerque, U. P., P. M. Medeiros, A. L. S. Almeida, J. M. Monteiro, E. M. F. Lins Neto, J. G. Melo, and J. P. Santos. 2007. Medicinal Plants of the Caatinga (Semi-Arid) Vegetation of NE Brazil: A Quantitative Approach. Journal of Ethnopharmacology 114:325-354. DOI:10.1016/j.jep.2007.08.017.

Albuquerque, U. P., P. M. Medeiros, W. S. Ferreira Júnior, T. C. Silva, R. R. V. Silva, and T. Gonçalves -Souza. 2019. Social-Ecological Theory of Maximization: Basic Concepts and Two Initial Models. Biological Theory 14:73-85. DOI:10.1007/ s13752-019-00316-8.

Bennett, B. C., and G. T. Prance. 2000. Introduced Plants in the Indigenous Pharmacopoeia of Northern South America. Economic Botany 54:90102. DOI:10.1007/BF02866603.

Bradacs, G., J. Heilmann, and C. S. Weckerle. 2011. Medicinal Plant Use in Vanuatu: A Comparative Ethnobotanical Study of Three Islands. Journal of Ethnopharmacology 137:434-448. DOI:10.1016/ j.jep.2011.05.050.

Brett, J. A., and M. Heinrich. 1998. Culture, Perception and the Environment: The Role of Chemical Perception. Angewandte Botanik 72:67-69.

Brewer, D. D. 2002. Supplementary Interviewing Techniques to Maximize Output in Free Listing Techniques. Field Methods 14:108-118. DOI:10.1177/1525822X02014001007.

Campbell, B. M., M. Luckert, and I. Scoones. 1997. Local-Level Valuation of Savanna Resources: A Case Study from Zimbabwe. Economic Botany 51:59_ 77. DOI:10.1007/BF02910405.
Cardoso, M. B., A. H. Ladio, and M. Lozada. 2017. Niche Breadth and Redundancy: Useful Indices to Analyse Fuelwood Use in Rural Communities. Journal of Arid Environments 145:52-59. DOI:10.1016/j.jaridenv.2017.05.007.

Chaves, L. S., A. L. B. Nascimento, and U. P. Albuquerque. 2019. What Matters in Free Listing? A Probabilistic Interpretation of the Salience Index. Acta Botanica Brasilica 33:360-369. DOI:10.1590/0102-33062018abb0330.

Ferreira Júnior, W. S., and U. P. Albuquerque. 2015. "Consensus within Diversity": An Evolutionary Perspective on Local Medical Systems. Biological Theory 10:363-368. DOI:10.1007/s13752-015-02151.

Geck, M. S., S. Cabras, L. Casu, A. J. R. García, and M. Leonti. 2017. The Taste of Heat: How Humoral Qualities Act as a Cultural Filter for Chemosensory Properties Guiding Herbal Medicine. Journal of Ethnopharmacology 198:499-515. DOI:10.1016/ j.jep.2017.01.027.

Giovannini, P. 2015. Medicinal Plants of the Achuar (Jivaro) of Amazonian Ecuador: Ethnobotanical Survey and Comparison With Other Amazonian Pharmacopoeias. Journal of Ethnopharmacology 164:7888. DOI:10.1016/j.jep.2015.01.038.

Güler, B., Y. Erkan, and E. Uğurlu. 2020. Traditional Uses and Ecological Resemblance of Medicinal Plants in Two Districts of the Western Aegean Region (Turkey). Environment, Development and Sustainability 22:2099-2120. DOI:10.1007/s10668018-0279-8.

Kahana, M. J. 1996. Associative Retrieval Processes in Free Recall. Memory \& Cognition 24:103-109. DOI:10.3758/BF03197276.

Menendez-Baceta, G., L. Aceituno-Mata, V. ReyesGarcía, J. Tardío, M. Salpeteur, and M. Pardo-DeSantayana. 2015. The Importance of Cultural Factors in The Distribution of Medicinal Plant Knowledge: A Case Study in Four Basque Regions. Journal of Ethnopharmacology 161:116-127. DOI:10.1016/j.jep.2014.12.007.

Miara, M. D., I. Teixidor-Toneu, T. Sahnoun, H. Bendif, and M. A. Hammou. 2019. Herbal Remedies and Traditional Knowledge of the Tuareg Community in the Region of Illizi (Algerian Sahara). 
Journal of Arid Environments 167:65-73. DOI:10.1016/j.jaridenv.2019.04.020.

Mickes L., T. M. Seale-Carlisle, and J. T. Wixted. 2013. Rethinking Familiarity: Remember/Know Judgments in Free Recall. Journal of Memory and Language 68:333-349. DOI:10.1016/ j.jml.2013.01.001.

Miranda T. M., M. C. M. Amorozo, J. S. Govone, and D. M. Miranda. 2007. The Influence of Visual Stimuli in Ethnobotanical Data Collection Using the Listing Task Method. Field Methods. 19:76-86. DOI:10.1177/1525822X06295987.

Monigatti, M., R. W. Bussmann, and C. S. Weckerle. 2013. Medicinal Plant Use in Two Andean Communities Located at Different Altitudes in the Bolívar Province, Peru. Journal of Ethnopharmacology 145:450-464. DOI:10.1016/j.jep.2012.10.066.

Nairne, J. S., S. R. Thompson, and J. N. S. Pandeirada. 2007. Adaptive Memory: Survival Processing Enhances Retention. Journal of Experimental Psychology: Learning, Memory, and Cognition 33:263-273. DOI:10.1037/02787393.33.2.263.

Ong, H. G., S. M. Ling, T. T. M. Win, D. Kang, J. Lee, and Y. Kim. 2018. Ethnobotany of Wild Medicinal Plants Used by the Müun Ethnic People: A Quantitative Survey in Southern Chin State, Myanmar. Journal of Herbal Medicine 13:91-96. DOI:10.1016/j.hermed.2017.09.006.

Pardo-de-Santayana, M., C. L. Quave, R. Sõukand, and A. Pieroni. 2015. Medical Ethnobotany and Ethnopharmacology of Europe. In Ethnopharmacology, pp. 343-356. John Wiley \& Sons, Ltd, Chichester,

UK. DOI:10.1002/9781118930717.ch29.

Quinlan, M. 2005. Considerations for Collecting Freelists in The Field: Examples from Ethnobotany. Field Methods 17:219-234. DOI:10.1177/1525822X05277460

Ramos, M. A., and U. P. Albuquerque. 2012. The Domestic Use of Firewood in Rural Communities of the Caatinga: How Seasonality Interferes With Patterns of Firewood Collection. Biomass and Bioenergy 39:147-158. DOI:10.1016/ j.biombioe.2012.01.003.
R Development Core Team. 2018. R: A Language and Environment for Statistical Computing. R Foundation for Statistical Computing, Vienna. 2018. Available at: https://www.r-project.org/about.html. Accessed on July 26, 2019.

Sandry, J., D. Trafimow, M. J. Marks, and S. Rice. 2013. Adaptive Memory: Evaluating Alternative Forms of Fitness-Relevant Processing in the Survival Processing Paradigm. PLoS ONE 8:e60868. DOI:10.1371/journal.pone.0060868.

Santos, C. S., F. N. Barros, M. Paula, J. Rando, V. T. Nascimento, and P. M. Medeiros. 2018. What Matters When Prioritizing A Medicinal Plant? A Study of Local Criteria for Their Differential Use. Acta Botanica Brasilica 32:297-302. DOI:10.1590/0102-33062017abb0336.

Shankar, U., R. Hedge, and K. S. Bawa. 1998. Extraction of Non-Timber Forest Products in the Forests of Biligiri Rangan Hills, India. 6. Fuelwood Pressure and Management Options. Economic Botany 52:320-336. DOI:10.1007/BF02862151

Silva, R. H., W. S. Ferreira Júnior, P. M. Medeiros, and U. P. Albuquerque. 2019. Adaptive Memory and Evolution of Human Naturalistic Mind: Insights from the Use of Medicinal Plants. PLoS ONE 14:e0214300. DOI:10.1371/journal.pone.0214300

Smith, J. J. 1993. Using ANTHROPAC 3.5 and a Spreadsheet to Compute a Free-List Salience Index. Cultural Anthropology Methods 5:1-3. DOI:10.1177/1525822X9300500301

Smith, J. J., and S. P. Borgatti. 1997. Salience Counts-And So Does Accuracy: Correcting and Updating a Measure for Free-List-Item Salience. Journal of Linguistic Anthropology 7:208-209. DOI:10.1525/jlin.1997.7.2.208

Sousa, D. C. P., G. T. Soldati, J. M. Monteiro, T. A. S. Araújo, and U. P. Albuquerque. 2016. Information Retrieval During Free Listing is Biased by Memory: Evidence from Medicinal Plants. PLoS ONE 11:e0165838. DOI:10.1371/journal.pone.0165838

Spillers G. J., and N. Unsworth. 2011. Variation in Working Memory Capacity and TemporalContextual Retrieval from Episodic Memory. Journal of Experimental Psychology: Learning, Memory, and Cognition 37:1532-1539. DOI:10.1037/a0024852. 
Suárez, M. E. 2019. Medicines in the Forest: Ethnobotany of Wild Medicinal Plants in the Pharmacopeia of the Wichí People of Salta Province (Argentina). Journal of Ethnopharmacology 231:525-544. DOI:10.1016/j.jep.2018.10.026.
Wu, J., J. Cheng, Z. Xu, K. Zhao, D. Zhao, M. Xie, H. Yang, L. Wen, K. Li, and H. Su. 2016. Nonlinear and Interactive Effects of Temperature and Humidity on Childhood Hand, Foot and Mouth Disease in Hefei, China. The Pediatric Infectious Disease Journal 35:1086-1091. DOI:10.1097/ INF.0000000000001238. 